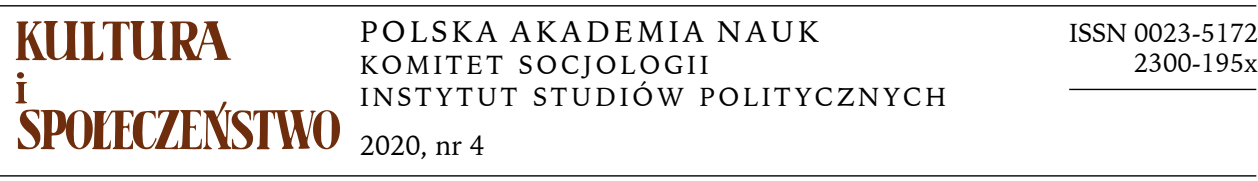
A $\mathbf{R}$
T Y
$\begin{array}{lllll}K & U & \mathbf{L} & \mathbf{Y}\end{array}$
I
$\begin{array}{lllllllll}\mathbf{R} & \mathrm{O} & \mathrm{Z} & \mathbf{P} & \mathbf{R} & \mathrm{A} & \mathrm{W} & \mathrm{Y}\end{array}$

MACIEJ KRYSZCZUK

Instytut Pracy $i$ Spraw Socjalnych

KAMIL SZYMAŃSKI

Uniwersytet Marii Curie-Skłodowskiej, Katolicki Uniwersytet Lubelski Jana Pawła II

\title{
INFORMACJA JAKO ARCHÉ - CZYLI ZARYS KONCEPCJI DATAIZMU YUVALA NOAHA HARARIEGO
}

\author{
„Wiedza to potęga"
}

Francis Bacon

\section{INFORMACJONALIZACJA I ARCHÉ}

Zgodnie ze stylem narracji Yuvala Harariego analizy zaczniemy od kwestii praktycznych, osobliwie osadzonych na pewnej funkcjonalnej społecznie fikcji epistemologicznej — zakładającej ogólnie, iż przetwarzanie informacji jest głównym sposobem kolaboracji organizmu (jednostka, podmiot) z rzeczywistością (percepcja rozszerzona, tożsamość). Organizm „kolaboruje” w tym sensie, iż jest ontologicznie odrębną od otoczenia całością, która ma prywatną epistemologię, osobiste cele oraz narzędzia poznawcze - mniej lub bardziej dostosowane do reguł społecznego komunikowania. „Gdziekolwiek spojrzeć — pisał historyk techniki George Dyson (1997, s. 218) — wszystko okazuje się bardziej rozumne i żywsze, niż się przedtem wydawało. Im bliżej poznajemy układy przetwarzania informacji, których doskonałym przykładem jest nasz mózg, tym bardziej przekonujemy się, że one działają jak układy ewolucyjne, a im bliżej poznajemy

Adres do korespondencji: maciej.kryszczuk@gmail.com; ORCID: 0000-0002-8543-8145; szym.kamil@gmail.com; ORCID: 0000-0002-9699-0541 
układy ewolucyjne, tym więcej odnajdujemy w ich funkcjonowaniu cech urządzeń przetwarzających informację". Zarówno w teorii informacji, jak i w dyskursie poświęconym społecznym skutkom tzw. informacjonalizacji pojawia się szereg specyficznych pojęć, których omówienie jest niezbędne do charakterystyki koncepcji dataizmu (Kryszczuk, Szymański 2019).

Termin „informacjonalizacja” oznacza proces stopniowego wzrostu znaczenia analizy danych dla trwania i replikacji danego systemu na poziomie zarówno jednostki, jak i grupy czy społeczeństwa, a szerzej — całej ludzkości. Znaczenie kulturowe procesu informacjonalizacji można określić na teoretycznej skali złożoności, na której determinizm technologiczny zajmuje pozycję skrajną. Jak pisał w roku 2013 Mateusz Halawa: „To, co techniczne - zapisane $\mathrm{w}$ algorytmie procedury kwantyfikacji i reguły rangowania treści, protokoły określające, jakie działania są $\mathrm{w}$ ramach systemu możliwe, a jakie nie, oraz interfejs, który pozwala przeżywać interakcję z maszyną jako «bycie wśród ludzi» - należy rozumieć jako materialną infrastrukturę uspołecznienia. Infrastruktura ta nie jest neutralna" (Halawa 2013, s. 119). Używane w naukach społecznych pojęcia metaforyczne, zgodnie $z$ językoznawstwem kognitywnym (Lakoff, Johnson 2020), związane są wielotorowo $z$ doświadczeniem (percepcją) i stanowią podstawę argumentacji Harariego w sporze o przyszłość cywilizacji.

Analizując koncepcję dataizmu warto pamiętać, iż pojęcie informacjonalizacji pojawia się $\mathrm{w}$ modernizacyjnych teoriach stadiów komunikacyjnych (Goban-Klas 2002, s. 15-17, 286-289). W zasadniczym swym dziele Rise of Network Society Manuel Castells (2000) pisał o procesie informacjonalizacji w sensie ogólnego wpływu technologii informacyjnych i komunikacyjnych na strukturę ekonomiczną, polityczną i społeczną. Na potrzeby tych rozważań proponujemy, aby informacjonalizacja zawierała się polu znaczeniowym pojęcia „modernizacja” - w tym sensie społeczeństwo bardziej zmodernizowane jest zarazem bardziej zinformacjonalizowane, to znaczy przetwarza więcej informacji, niekoniecznie rozumiejąc ich sens. Natomiast pojęcie informacjonalizacji jest szersze od pojęcia informatyzacji, gdyż: 1) obejmuje dodatkowo zjawiska ze sfery społecznej (tj. zmiany w systemach edukacji); 2) nie rozstrzyga o rodzaju mediów i urządzeń, za pomocą których przetwarza się dane i kontroluje uwagę podmiotów (centralnie, hierarchicznie, demokratycznie, losowo itd.); 3) pozostawia otwartą kwestię architektury semantycznej i logiki algorytmów SI, która wynikać będzie - do czasu zaistnienia niekontrolowanej osobliwości - z decyzji politycznych i gospodarczych, osadzonych gruntownie w szeroko rozumianej sferze kultury (obyczaje, język, prawo, sztuka, religia, nauka itp.). Wątek informacjonalizacji jako praprzyczyny porządku i zmia- 
ny społecznej, razem z dość śmiałymi wnioskami z zakresu biologii, został rozwinięty przez Harariego w Homo deus. Krótka historia jutra (2018). Książka ta została przetłumaczona na kilkadziesiąt języków, stając się światowym bestsellerem. Jest także szeroko komentowana, zarówno w prasie, jak i w środowisku naukowym.

Innym terminem, który należy przybliżyć, jest pojęcie arché. Wykorzystywane jest ono $\mathrm{w}$ charakterystyce stanowisk filozofów przedsokratejskich. Jak podaje Giovanni Reale $(2008$, s. 76,81$)$, terminu tego po raz pierwszy miał użyć Anaksymander w celu określenia primum - pierwszej i ostatecznej zasady rzeczywistości. Głównym celem filozofów tego okresu była próba wskazania najważniejszego - podstawowej zasady rzeczywistości, z której wywodzi się wszystko to, co istnieje. Na przykład Tales za arché uznawał wodę, a według Anaksymanesa było nią powietrze. Filozofowie przedsokratejscy, stawiając sobie ambitny cel wyjaśnienia przyczyn istnienia rzeczywistości, dokonywali zarazem znaczącej jej redukcji do jednego, wybranego przez nich żywiołu lub elementu. Sposób formułowania przez nich własnych stanowisk był związany z poziomem wiedzy przyrodniczej ówczesnego okresu. W toku analizy stanowiska Harariego można dostrzec, że on także, wzorem wczesnych filozofów, dokonuje znaczącej redukcji złożonej rzeczywistości - do postaci informacji.

\section{STRUKTURALNE UWARUNKOWANIA DATAIZMU}

$\mathrm{Z}$ nastaniem roku 2018 jeden $\mathrm{z}$ blogerów zamieścił na autorskiej stronie komentarz (który może zostać uznany także za element manifestu XXI wieku) do książki Harariego, popularyzatora idei dataizmu: „Uchylimy naszą prywatność, aby zyskać możliwość dłuższego życia w lepszym zdrowiu. To jest właśnie sedno opisywanej przez Yuval Noah Harariego nowej religii - dataizmu. Będziemy się dzielić ze sztuczną inteligencją wszystkim co nas dotyczy, za obietnicę lepszego życia. [...] Maszyna postawi lepszą diagnozę, niż lekarz dowolnej specjalizacji, dokładniej policzy prawdopodobieństwo wystąienia jakiegoś zjawiska oraz nie ulegnie stronniczości opinii. Podjęte przez sztuczną inteligencję wybory są więc bardziej optymalne, w porównaniu z ludzkimi. [...] I oczywiście mogą się zdarzyć sytuacje, gdy w pojedynczych przypadkach człowiek podejmie decyzję lepszą niż maszyna. Ale to się dzieje coraz rzadziej. A kto z nas chciałby wieść życie, w którym podejmie same złe decyzje?" 1.

${ }^{1}$ Blog Rafała Kinowskiego (http://antykruchosc.blox.pl/2018/01/Dataizm.html [dostęp: 18.06.2018]). 
Wizja podejmowania wyłącznie dobrych — w sensie racjonalnej optymalizacji - decyzji dla wielu ludzi jest czymś naturalnie kuszącym. Do tego stopnia, że indywiduum (zapewne nie każda osoba) jest w stanie zrezygnować z możliwości ryzyka życiowego, związanego $z$ autonomicznymi wyborami. Można się oczywiście nadal spierać, do jakiego stopnia postawa dataistyczna jest zgodna bądź nie $z$ - dajmy na to - etyką postulowaną przez Immanuela Kanta w pracy Co to jest oświecenie?, w której przekonywał on do świadomego, krytycznego i samodzielnego posługiwania się rozumem (Kant 2005, s. 44-49). W XXI wieku tzw. życie 3.0 zmierza nieuchronnie w kierunku superinteligencji, korzystającej $z$ algorytmów karmionych big data (Tegmark 2019). Habitat typowego ziemianina staje się „wielkim zbiorem” danych, które można zarchiwizować, przetworzyć, odczytać, przeanalizować ponownie oraz skutecznie wykorzystać do osiągnięcia zamierzonych celów (ponad połowa ludzi na świecie ma dziś dostęp do internetu). Informacjonalizacja jest wygodnym terminem, podkreślającym informacyjną wagę przemian cywilizacyjnych ${ }^{2}$.

Zachodzący prężnie proces digitalizacji jest jednym z czynników (etapów, wariantów, elementów) procesu informacjonalizacji, ikoną którego stał się mobilny internet. Obsługujące zapotrzebowanie konsumentów „silniki SI” uczą się na bazie własnych błędów, co czyni je otwartymi także na absurdy, masowo generowane przez miliardy internautów. Biorąc pod uwagę całościowe ujęcie postaci ludzkiej (osoby, jednostki, tożsamości), inteligentny system ma dwa skrajne wyjścia: 1) wyeliminować możliwości perswazyjne wolnych od racjonalnej kontroli grup wpływu, których aktywność prowadzi do chaosu epistemologicznego (szczepionki są dobre czy złe?); 2) pozwolić wszystkim na profesjonalizację i urynkowienie własnych pomysłów, co daje kontrolę nad ewentualnymi rozbieżnościami doktryny i praktyki. Skrajne rozwiązania otacza się kordonem bezpieczeństwa, dlatego też dataizm jest programowo otwarty (w Popperowskim

${ }^{2}$ Termin „informacjonalizacja” jest propozycją jednolitego ujęcia ogólnej treści teorii informacji, na którą składają się: 1) technologie komunikowania (zasilanie energetyczne, technika przesyłu i metody kodowania danych), które formalnie oddają typowy sens pojęcia: głosu, orkiestry, kaligrafii, druku, cyfryzacji czy internetyzacji; oraz 2) policzalne koszty magazynowania newralgicznych danych z potencjalizacją informacyjną zgromadzonego archiwum (obecnie częściowo pokrywane przez „model za darmo”, marketing i reklamę, częściowo przez akcjonariuszy); 3) organizacja opinii publicznej, czyli kontrola nad procesem przyciągania uwagi różnych audytoriów, elektoratów i publiczności. W odniesieniu do teorii stadiów komunikacyjnych terminu „informacjonalizacja” należy używać w relacji do pojęcia „modernizacja”. 
sensie) ${ }^{3}$. Zapotrzebowanie na inteligentne algorytmy rośnie wprost proporcjonalnie do chaosu, który generują sami ludzie (bazą źródłową są użytkownicy internetu). Przedstawienie argumentacji Harariego pozwoli na prześledzenie głównych wątków spojrzenia na kulturę i społeczeństwo u progu XXI wieku.

\section{ISTOTA DATAIZMU}

Pierwszy raz terminem „dataizm” posłużył się David Brooks z gazety „New York Times” w artykule pt. The Philosophy of Data ${ }^{4}$. Stwierdził, że stoimy u progu upowszechnienia nowego rodzaju filozofii, która zakłada, że wszystko, co jest możliwe do zmierzenia, powinno zostać zmierzone. Informacje zaczynają stanowić najważniejszy element rzeczywistości, przez co ich posiadanie zaczyna być coraz bardziej znaczące. Szczególne znaczenie odgrywa $\mathrm{w}$ tym kontekście rozwój internetu, który znacznie przyspieszył przesyłanie informacji w skali całego globu. Jak wielu innych dziennikarzy, piszących często w sposób ogólnikowy, David Brooks zwraca szczególną uwagę na to, że statystyka pozwala przewidywać określone wyniki w sporcie, w polityce (np. podczas wyborów), w sferze konsumpcji i spraw powszednich. Epistemologiczna filozofia dataizmu sformułowana przez Brooksa zyskuje jednak coraz większą popularność, z racji rosnącego wykorzystywania narzędzi cyfrowych do kształtowania „nowego świata", a także rosnącego zainteresowania badaczy oraz mediów rozwojem Sztucznej Inteligencji (SI) czy narzędzi telekomunikacyjnych.

Harari, podobnie jak jońscy filozofowie przyrody i wielu innych myślicieli, analizuje istnienie naczelnej, fundamentalnej zasady rzeczywistości, którą jego zdaniem jest informacja (Harari 2018, s. 411). Ta naczelna zasada polega na tym, że „wszystko” można sprowadzić do przeliczania danych - fizycznych, biochemicznych, społecznych. Harari przypomina sukces O powstawaniu gatunków Karola Darwina oraz maszynę Turinga jako kro-

${ }^{3}$ Analizę danych na masową skalę wykorzystano podczas opisu rozprzestrzeniania się wirusa H1N1 w Stanach Zjednoczonych w 2009 roku. Algorytmy Google'a, posiadające dane dotyczące wirusa grypy, pozwoliły na przewidzenie sposobów rozprzestrzeniania się świńskiej grypy, a w rezultacie opanowanie wirusa i zabezpieczenie przed zachorowaniem ludzi. Algorytmy „uczyły się” od 2003 do 2008 roku, opierając się na wyszukiwaniu przez użytkowników Google’a słów kluczowych dotyczących grypy (np. jakie są objawy..., czy jak wyleczyć...), a także posiadając informacje dotyczące lokalizacji użytkowników. Wyszukiwanie pokrywało się z rozprzestrzenianiem się i formowaniem ognisk chorobowych (Mayer-Schönberger, Cukier 2014, s. 1-2).

${ }_{4}$ David Brooks, The Philosophy of Data (https://www.nytimes.com/2013/02/05/opinion/ brooks-the-philosophy-of-data.html [dostęp: 20.12.2020]). 
ki milowe przejścia do obecnej sytuacji (Harari 2018, s. 414). Człowiek został zredukowany do puli genów, to jest informacji genetycznych ${ }^{5}$, które nie różnią się jakościowo w żaden sposób od informacji kodowanych przez naturę. Oddaje on także świadomie pole postępowi, pozwalającemu na konstruowanie coraz bardziej zaawansowanych algorytmów, zdolnych do użytkowego przetwarzania coraz większej liczby danych. Na tych założeniach ufundowana jest koncepcja dataizmu Harariego - wszystko jest policzalną informacją, niezależnie od tego, czy mówimy o człowieku, odległej planecie czy głowonogach. Jednocześnie to technika, a konkretnie algorytmy i komputery są $\mathrm{w}$ stanie przetwarzać dane $\mathrm{w}$ ilościach, których nie jest w stanie przetworzyć żaden pojedynczy mózg. Oto dataistyczna definicja kultury: uporządkowany celowo zbiór informacji. „Dataizm głosi, że wszechświat składa się z przepływu danych, a wartość każdego zjawiska czy bytu określa jego wkład w przetwarzanie danych. [...] Dataizm zestawia jedne $z$ drugimi, zwracając uwagę, że zarówno do algorytmów biochemicznych, jak i do elektronicznych znajdują zastosowane dokładnie te same zasady matematyczne. Tym samym dataizm obala barierę między zwierzętami a maszynami i spodziewa się, że algorytmy elektroniczne w końcu rozszyfrują i prześcigną algorytmy biochemiczne" (Harari 2018, s. 412).

W świecie zbudowanym na permanentnej analizie danych zasadniczą rolę odgrywa proces komunikacji społecznej, w którym aktywny udział biorą konkretni ludzie, wyznający zasadę, by: „[...] pozyskiwać informacje, gdziekolwiek są przechowywane, kopiować je i dzielić się nimi ze światem. [...] By przekonać sceptyków, dataistyczni misjonarze bezustannie tłumaczą, jak olbrzymie korzyści niesie ze sobą wolność informacji. Tak jak kapitaliści wierzą, że wszystko, co dobre, zależy od wzrostu gospodarczego, tak dataiści wierzą, że wszystko, co dobre - w tym wzrost gospodarczy zależy od wolności informacji" (Harari 2018, s. 430-431). Z perspektywy dataisty informacją może być wszystko, co można zakomunikować i replikować: „Według dataizmu V symfonia Beethovena, bańka giełdowa i wirus grypy to tylko trzy wzory przepływu danych, trzy prawidłowości, które można analizować z użyciem tych samych podstawowych pojęć i narzędzi" (Harari 2018, s. 412). Niezmiennie fundamentalne bytowanie w świecie przeżywanym (doświadczenia zmysłowe, qualia, obraz manifestujący się) związane jest $z$ tym, że dany wytwór nie odbiega u swych podstaw istnienia od każdego innego wytworu zgodnego z prawami fizyki, oba zaś

\footnotetext{
${ }^{5}$ Oczywiście nastąpiło to później na skutek rozwoju badań biologicznych. Jednak pojawienie się teorii ewolucji miało znaczący wpływ na dalszy rozwój nauki.
} 
są jedynie zlepkiem uporządkowanej systemowo informacji. Tego rodzaju przekaz proponowany jest $\mathrm{w}$ dataizmie na poziomie rozważań ogólnych dla humanistów, praktycznym celem jest zaś utrzymanie dostępu do źródła wiedzy, przetworzenie ich, a następnie zbudowanie systemu wyjaśniającego rzeczywistość (Harari 2018, s. 412-414), efektywnego w realizacji celów politycznych czy gospodarczych.

Dla współczesnego kapitalizmu nie ma znaczenia, jaka funkcja jest przypisana określonemu towarowi. Kultura zostaje pozbawiona swej symboliki, a wytwory swych lokalnych sensów. W miejsce kondensacji uwagi konsumenta powstają inne sensy, związane bezpośrednio z komunikowaną medialnie treścią (reklama). Jako przykład często podaje się zjawisko „marki” (brand), która „działa między kulturą a gospodarką, łącząc lokalne symbole, znaczenia i rozpoznawalne przeżycia z globalnym systemem dystrybucji usług i towarów. Pośredniczy między życiem wewnętrznym konsumentów a interesem producentów (zorientowane psychologicznie badania rynku posługują się pojęciem marki, by ramować towary jako odpowiedzi na funkcjonalne i emocjonalne "potrzeby» ludzi). Mediuje pomiędzy afektywnymi jakościami życia codziennego a ilościową logiką pomiaru (narzędzie brand equity ma zdolność przeliczania «emocjonalnego wizerunku» na pieniądze)" (Halawa 2013, s. 137).

Z kolei dla dezyderatu decyzyjności władzy państwowej kluczowe jest utrzymanie „stanu umysłu” wyborczej publiczności na właściwym z punktu widzenia efektywności komunikacji - poziomie kompetencji poznawczych. Drugą opcją zachowania skuteczności systemu wolnego rynku jest polemika ze stanowiskiem ekspertów, którzy chcą kontynuować dociekania sprawiedliwości pod racjonalną ochroną instytucjonalną (regulacje prawne i kodeksy etyki). Nie tylko ze względu na złożoność organizacji pracy badaczy polityczne sprawy decyzyjności komplikują się w wyniku informacjonalizacji, która utrudnia centralną kontrolę przepływu danych, informacji czy wiedzy. Imposilibizm wobec pewnych rozwiązań skłania do podjęcia właściwych kroków w kierunku unormowania sytuacji społecznej regionalnie (np. poprzez zakwestionowanie rządów prawa). Tak rodzi się neoluddystyczny partykularyzm wtórny, filozoficznie ujęty przez Daniela Dennetta w metaforę „od bakterii do Bacha” (Kryszczuk 2018) ${ }^{6}$.

${ }^{6}$ Dennett w angielskim podtytule książki dodaje „i z powrotem” (and back), co w polskim przekładzie sugerowałoby sceptycyzm wobec bezwzględnego kierunkowania procesu cywilizacji. Czy osiągnąwszy demokratyczny etap bachowskiej wirtuozerii kompozycyjnej zapragniemy powrotu do plemienności disco polo? 


\section{INTELIGENTNY CZŁOWIEK W EPOCE DATAIZMU}

W dataistycznej wizji formułowanej przez Harariego wyraźnie obecny jest redukcjonizm, który dotyka istoty człowieka. Redukcja ta formułowana jest nie tylko na poziomie ontycznym, gdyż Harari powtarza znane wnioski dotyczące kondycji człowieka. Według niego, w epoce danych „ludzkie doświadczenia nie są święte, a homo sapiens nie jest szczytem stworzenia ani prototypem jakiegoś przyszłego homo deus. Ludzie są jedynie narzędziami do tworzenia Internetu wszystkich rzeczy" (Harari 2018, s. 427). Człowiek dziś staje się jedynie twórcą informacji, które przetwarzają algorytmy w celu optymalizacji wyboru, takiego jak skorzystanie z usługi taksówkarza czy kierowcy Ubera? Lepiej wybrać serwującą azjatyckie potrawy restaurację mającą 4,4 gwiazdki w ocenie na platfomie Google czy włoską pizzerię z 4,8 gwiazdki? Instytucjonalizacja ekonomiczna danej usługi informacyjnej oznacza zazwyczaj jej wiarygodność, stabilność i bezpieczeństwo, wyradzające się w szacunek i poparcie społeczne (social media) (Halawa 2013, s. 120-121). Pierwszą z charakterystyk dataizmu jest zatem podłączenie systemu-świata do internetu, włączenie wszystkiego, co tylko możliwe technicznie i ekonomicznie, do inteligentnej sieci przedmiotów i systemów zarządzania dużymi bazami danych (big data). Zasada druga zakłada, że zarówno blokada informacyjna, jak i nadmierna inwigilacja stanowią grzechy główne dataizmu, ponieważ są bezpośrednią i siłową (przemocową) ingerencją w swobodę partycypacji obywatelskiej (Harari 2018, s. 428-429). Wielość dostępnych kanałów informacyjnych jest poważną barierą dla propagandowej efektywności agendy władzy, która selekcjonuje i ograniczenia wiadomości: atrakcyjność i przypadkowość (emergentność) - wyrafinowanie i skuteczność komunikatów, w powiązaniu z efektem skali komunikacji sieciowej, przynosi niekiedy zaskakujące rezultaty wyborcze.

Jeśli kultura zostaje zredukowana do zbioru informacji, to ich rozumne objaśnienie staje się możliwe dzięki ich wykorzystaniu na masową skalę. Raymond Kurzweil (2013, s. 66) zauważa, że zgodnie z prawem Moore'a, co 12 miesięcy (przy czym u początku rozwoju przemysłu komputerowego były to 24 miesiące) podwajała się liczba tranzystorów w układzie scalonym. Zakładając, że mózg ludzki posiada określoną ilościowo moc obliczeniową, to rozwój kultury technicznej musiał doprowadzić do momentu przekroczenia zdolności, którymi dysponował pojedynczy człowiek (głównie w zakresie operacji symbolicznych). Filozof Daniel Dennett przypomina, że mniej więcej 40-20 tysięcy lat temu przyspieszyła akumulacja wiedzy symbolicznej, ponieważ bardziej ukierunkowane oraz scentralizowane stawianie problemów doprowadziło do skuteczniejszego ich rozwiązywania: 
„Wśród niezbędnych innowacji są takie genialne "wynalazki», jak pismo, arytmetyka, pieniądze, zegary i kalendarze, a każdy z nich przyczynił się do powstania nowego i płodnego systemu reprezentacji. Wyposażył on nasz obraz manifestujący się w jeszcze bardziej przenośne, odłączalne, dające się manipulować i rozpoznawać, niezapomniane rzeczy do robienia innych rzeczy, do używania w celu coraz lepszego opanowania innych rzeczy. Były to, o ile nam wiadomo, darwinowskie "wynalazki», to znaczy wynalazki bez wynalazców lub przewidujących autorów. [...] Te racje bezpodmiotowe ${ }^{7}$ cech i struktur owych wynalazków zostały stopniowo uchwycone, przedstawione i docenione przez późniejszych beneficjentów, retrospektywnych inżynierów odwrotnych. [...] Wszystkie te kulturowo przekazywane artefakty, abstrakcyjne lub konkretne, są bezbłędnie zaprojektowanymi narzędziami do myślenia, które nie były pomysłami poszczególnych indywidualnych inteligentnych projektantów" (Dennett 2017, s. 404-405).

W koncepcji Dennetta artefakty musiały się pojawić, gdyż uzależnione od ich powstania było przeżycie gatunku homo. Jednocześnie zaistnienie jednego prowadziło do pojawienia się kolejnego, tworząc „drzewo rozwoju”. „Zdajemy sobie sprawę, że nasz gatunek nie jest bardziej odporny na wyginięcie niż wszystkie [...]. Czy jednak kiedykolwiek przyszło nam do głowy, że ta epoka rozumiejących bohaterów może po prostu dobiegnie kresu, podczas gdy Homo sapiens będzie się nadal rozmnażać, a jego miano myślącego człowieka zdezaktualizuje się? Są pewne niepokojące oznaki, że stajemy się nadmiernie ucywilizowani dzięki pomysłowości wszystkich oszczędzającym nam pracy i uzależniających wynalazków i że wchodzimy W erę postinteligentnego projektu" (Dennett 2017, s. 489-490). Scenariusz odebrania pracy przez roboty i algorytmy jest stale obecny w popkulturze, prasie popularnonaukowej, a przy okazji większych osiągnięć z pola naukowo-technicznego przenika do debaty publicznej jako news. Co do tego, czy i jak sytuacja się rozwinie, nie ma jednak powszechnej zgody (Szymański 2017).

\section{ALGORYTMY I CYWILIZACJA}

Harari, postrzegający ludzi jako systemy przetwarzania danych (na przykład jak procesory), formułuje tezę o czterech historycznych etapach postępu ludzkości. Pierwszy etap polegał na wzroście ilości przetwarza-

7 Dennett wprowadził pojęcie „racji bezpodmiotowych” (free-floating rationales) w latach osiemdziesiątych XX wieku i wielokrotnie później omawiał je w kontekście inżynierii odwrotnej (reverse engineering). 
nych danych, związanym ze stopniowym przyrostem ludzi w sensie gatunkowym. Liczba osób należących do danej gromady czy państwa wpływała na wydajność przetwarzania przez nich danych, tak jak liczba tranzystorów w mikroprocesorze wiąże się z możliwością przetwarzania danych przez komputer. W drugim etapie poszczególni ludzie zaczęli się od siebie różnić, co przełożyło się na różnorodne sposoby interpretowania danych, co po części powiązane jest ze światopoglądem poszczególnych osób z poszczególnych grup społecznych. Trzeci etap, powiązany z procesami globalizacyjnymi, pozwolił na migrację danych (i informacji) na przykład przez szlaki handlowe. Stykanie się z różnorodnymi poglądami stanowi jeden $z$ istotnych stymulatorów kreatywności, która przyczynia się do dalszych przemian świata. W ostatnim opisywanym przez Harariego czwartym etapie istotne stało się uwolnienie danych i pozwolenie na ich swobodny przepływ. Wynalazkiem, który najbardziej do tego się przyczynił, były sieci cyfrowe, umożliwiające swobodną wymianę myśli pomiędzy ludźmi na całym świecie (Harari 2018, s. 425). W dataistycznej perspektywie każdemu z tych etapów towarzyszyły nowe wyzwania egzystencjalne uczestników (jednostek) komunikacji społecznej. Jednak ostateczne konsekwencje realizacji zamysłu dataistycznego mają być dla człowieka katastrofalne. Jeśli ludzkość rzeczywiście jest jednym systemem przetwarzania danych, to co stanowi jego dane wyjściowe? Dataiści powiedzieliby, że te dane wyjściowe stanowi stworzenie nowego i jeszcze skuteczniejszego systemu przetwarzania danych, zwanego internetem wszystkich rzeczy. Z chwila gdy ta misja zostanie zakończona, homo sapiens zniknie (Harari 2018, s. 427).

Technika „opanowuje” poszczególne sfery aktywności ludzkiej, oferując różnego rodzaju ułatwienia, których paradoksalnie często trzeba na nowo się uczyć. Jednocześnie brakuje spójnej alternatywy dla naukowo-technicznego systemu, co zauważyli już Konfucjusz, Mahomet czy Neil Postman w 1992 roku (Postman 1995, s. 65). Proces informacjonalizacji, którego syndromem jest obecnie dataizm, sprzyja rozwojowi i komercjalizacji technologii cyfrowych, na czym prima facie korzystają zarówno politycy, biznesmani, naukowcy, jak i zwykli ludzie, ale zyski nie są dystrybuowane równomiernie (Harari 2018, s. 412). Jako przewrotną anegdotę można przytoczyć słowa George’a B. Dysona (1997, s. 197, 200-201): „Banki komercyjne istnieją od 600 lat. Komputery mają mniej niż 60 lat. Firmy wytwarzające oprogramowanie do mikrokomputerów mają 20 lat i raz po raz wynajdują koło. Jeśli wierzymy w zbieżność, jak myślicie, kto pierwszy nauczy się fachu drugiej strony? [...] Podczas fuzji producentów oprogramowania, bankowości i telekomunikacji płodzimy prekursorów kolektywnych cyfrowych organizmów, które rozłażą się po sieci niczym 
owady społeczne, przesyłając pakiety cyfrowych pieniędzy z powrotem do swoich gniazd". Uzależnienie systemu finansowego od wiedzy sterującej procesami społeczno-gospodarczymi wchodzi obecnie w kolejną fazę informacjonalizacji, w której — jak pisze José van Dijck (2014, s. 197) — dane są już walutą świata. „W obrębie społeczeństwa ludzkiego pieniądz spełnia rolę miernika i pośrednika w celu osiągania spadku entropii na lokalnych rynkach, czy też określa stopień czystości uncji złota, energię tony węgla, wartość akcji wielkiej korporacji lub przydatność informacji zawartej w książce" (Dyson 1997, s. 200).

Także sami ludzie, a konkretnie informacje do nich przypisane zostają wycenione na określoną kwotę, w zależności od tego, czy „kupują” je firmy związane $z$ marketingiem, czy korporacje zajmujące się zbieraniem informacji genetycznych o poszczególnych jednostkach. Praktykowany w biznesie informacyjnym model „za darmo” żywi się danymi, które ofiarowują (za darmo) jego klienci. O negatywnych skutkach "handlu informacją" pisze dziś wielu autorów (Spitzer 2013). Facebook zagroził wręcz całkowitym wycofaniem się z rynku Unii Europejskiej na skutek decyzji irlandzkiej Komisji Ochrony Danych, która wydała wstępny nakaz zaprzestania przesyłania danych europejskich użytkowników na serwery w Stanach Zjednoczonych ${ }^{8}$. Na szali leżą tu prywatność i własność danych poszczególnych ludzi oraz ich wartość ekonomiczna, tak istotna dla współczesnych korporacji bazujących na ich przetwarzaniu.

Paradoksalnie internet, który miał zapewnić ludziom wolny dostęp do informacji, zarówno w zakresie uzyskiwania, jak i przekazywania, stając się synonimem demokracji, rozwija się w różnych kierunkach. „Prawdopodobnie w nadchodzących dziesięcioleciach będziemy świadkami kolejnych rewolucji podobnych do internetowej, podczas których technologia będzie wyprzedzała politykę. Sztuczna inteligencja i biotechnologia mogą wkrótce wyprzedzić nasze społeczeństwo i gospodarki - a także nasze ciała i umysły - ale obecny polityczny radar ich praktycznie nie widzi. Dlatego liberalno-demokratyczna doktryna traci kontrolę nad wydarzeniami i nie przedstawia sensowych wizji przyszłości [...]. Zwykli wyborcy zaczynają przeczuwać, że tradycyjne mechanizmy demokratycznie już nie dają im władzy. Świat zmienia się wszędzie wokół, a oni nie rozumieją jak ani dlaczego. Władza się od nich oddala, ale nie wiedzą dokąd" (Harari 2018, s. 421).

${ }^{8}$ Facebook zagrozit, że może być zmuszony zablokować Europejczykom dostęp do swych usług, „Dziennik Gazeta Prawna” (https://serwisy.gazetaprawna.pl/media/artykuly/1492066,face book-dostep-do-uslug-uodo-wyrok-tsue.html [dostęp: 20.12.2020]). 
Cokolwiek by sądzić o skutkach informacjonalizacji, dla rosnącej rzeszy obywateli komunikacja sieciowa jest ucieleśnieniem i derywatem wolności obywatelskiej i swobodnej gry rynkowej (homo eligens), tyle że przedmiotem wymiany są narracje utkane z memów (abstraktorów), które to propagandowe „atrakcyjne koszyki abstrakcji” są w demokracji ważnym źródłem i zarazem narzędziem partycypacji politycznej oraz ochrony wolności kulturowej. Podobnie, powiadają socjaldemokraci, jak każdy może zostać milionerem, tak każdemu przypada egalitarny przydział prawa do własnej tożsamości (osobistego koszyka atrakcyjnych abstrakcji).

\section{DANE KONTRA CZŁOWIEK}

Sprowadzenie człowieka do postaci danych, które niczym nie różnią się od danych pochodzących od innych istot czy obiektów, może prowadzić do marginalizowania roli świadomości człowieka, będącej osobliwością W znanym nam wszechświecie. Na gruncie dataizmu funkcjonuje przekonanie o tym, że ludzie „zrealizowali swoje zadanie” (Harari 2018, s. 394). Może to oznaczać, że: a) ludzie nie są odpowiednimi podmiotami do realizowania założeń dataizmu, b) istnieją (lub mogą zaistnieć) inne, bardziej odpowiednie podmioty zdolne realizować te założenia. Jednak według Harariego (2018, s. 394), aktualnie ścierają się dwa rodzaje „technoreligii” technohumanizm i dataizm. Jeśli chodzi o charakterystykę technohumanizmu ${ }^{9}$, to jest on przezeń opisywany w następujący sposób: „Ten pomysł jest unowocześnionym wariantem dawnych marzeń humanizmu ewolucyjnego, który już przed stu laty wzywał do stworzenia nadludzi. Jednakże podczas gdy Hitler i jemu podobni planowali tworzyć nadludzi za pomocą sztucznej selekcji i czystek etnicznych, technohumaniści XXI wieku mają nadzieję osiągnąć ten cel $\mathrm{w}$ dużo spokojniejszy sposób - za pomocą inżynierii genetycznej, nanotechnologii i interfejsów mózg-komputer" (Harari 2018, s. 395). Technohumanizm bazuje na najnowszych osiągnięciach nauki, dzięki którym możliwe będzie stworzenie nowego rodzaju homo, którego Harari (2018, s. 394) nazywa homo deus. Ogólna charakterystyka tego typu ewolucji oraz sposobów jej realizacji (wykorzystanie nauki i techniki) sugeruje, że używając terminu „technohumanizm” Harari (2018, s. 395) ma na myśli współczesny nurt transhumanistyczny ${ }^{10}$.

\footnotetext{
${ }^{9} \mathrm{~W}$ anglojęzycznej wersji książki Harari posługuje się pojęciem techno-humanism (Harari 2016, np. s. 366).

10 Termin „transhumanizm” ma ugruntowaną pozycję w dyskursie akademickim oraz popularnonaukowym (Bobryk 2014, s. 9-27; Gałuszka i in., 2016).
} 
Yuval Harari (2018, s. 411) pisze: „Technohumanizm staje przed niemożliwym do rozstrzygnięcia dylematem. Uważa, że ludzka wola to najważniejsza rzecz we wszechświecie, dlatego nakłania ludzkość do opracowywania rozwiązań technicznych, które pozwolą kontrolować i przeprojektować wolę. No bo przecież to kusząca myśl: zdobyć kontrolę nad najważniejszą rzeczą w świecie" 11 . Harari widzi w transhumanizmie zagrożenie, które doprowadzi do ubezwłasnowolnienia świadomości ludzkiej. Problem w tym, że tego rodzaju zabiegi odbywają się już teraz, czy to przez sprytne wykorzystywanie zabiegów socjotechnicznych, czy odpowiednie filtrowanie treści, które otrzymujemy w wyszukiwarkach czy nawet na osi czasu $\mathrm{w}$ dowolnym medium społecznościowym.

W odróżnieniu od dataizmu technohumaniści tacy jak Max More i Natasha Vita-More twierdzą (2013), iż homo sapiens to gatunek wyjątkowy, który należy ulepszać (Harari 2018, s. 394). Zdaniem Harariego tego typu założenie jest naiwne, gdyż nawet „udoskonalony” człowiek nie przewyższy umiejętności sztucznej inteligencji. „Według dataizmu ludzkie doświadczenia nie są święte, a homo sapiens nie jest szczytem stworzenia ani prototypem jakiegoś przyszłego homo deus. Ludzie są jedynie narzędziami do tworzenia Internetu wszystkich rzeczy, który w końcu może rozprzestrzeni się z naszej planety dalej i przeniknie całą galaktykę, a nawet cały wszechświat" (Harari 2018, s. 427). Ulepszeni za pomocą osiągnięć bioinżynieryjnych ludzie nie będą w stanie w odpowiedni sposób przetwarzać olbrzymiej ilości informacji w taki sposób, do jakiego mają być zdolne algorytmy komputerowe. Człowiek w przyszłym świecie dataistycznym będzie: a) zbiorem analitycznych informacji, b) twórcą wiedzy, którą wykorzystają superinteligentne maszyny. Dataizm sprowadza więc człowieka do rangi jednego z wielu „elementów” rzeczywistości, takiego, który nie różni się jakościowo od artefaktów. Różnica staje się wyłącznie ilościowa, a człowiek zdecydowanie traci swoją uprzywilejowaną pozycję, którą posiadał w myśl dotychczasowych koncepcji filozoficznych oraz religijnych.

Według Harariego dataizm, choć marginalizuje, jak się wydaje, rolę człowieka, to nie ma na celu „walki” z ludźmi. „Dataizm nie jest ani liberalny, ani humanistyczny. Należy jednak podkreślić, że dataizm nie jest antyhumanistyczny. Nie ma nic przeciwko ludzkim doświadczeniom. Nie

\footnotetext{
${ }^{11}$ Harari ma tu prawdopodobnie na myśli jeden $\mathrm{z}$ postulatów formułowanych $\mathrm{w}$ obrębie transhumanizmu. Max More w Liście do matki natury (2013, s. 344-345), wymieniając siedem postulatów niezbędnych do „poprawy” elementów człowieka, w punkcie szóstym wskazuje, że konieczne jest także wprowadzenie narzędzi prowadzących do wzrostu racjonalności człowieka przez wyeliminowanie lub ograniczenie wpływu emocji na jego decyzje i działania.
} 
uważa tylko, by z natury rzeczy miały one jakąkolwiek wartość" (Harari 2018, s. 435). Potrzeby, cele, wartości, którymi posługuje się człowiek, są istotne tylko dla niego samego. Gdy zostaną sprowadzone do postaci informacji, na przykład wpisu na Twitterze czy Facebooku, dla algorytmu komputerowego nie różnią się na przykład od informacji pogodowej, komunikatu o śmierci prezydenta czy trasie przejazdu w nawigacji (Halawa 2013). W świecie algorytmów wielkie doktryny polityczne czy moralne konkurują z chaotycznym strumieniem informacji o cyfrowej codzienności przeciętnych ludzi. Drugą stroną użytkowego medalu SI jest inwigilacja, komercyjne profilowanie (big data) oraz powstawanie baniek informacyjnych.

Tu uwydatnia się problem polityzacji dataizmu i dalszych losów sztucznej inteligencji. Mimo że algorytmy są w stanie analizować znacznie szybciej i znacznie większe ilości informacji, to nie są jeszcze w stanie nadać im sensu ${ }^{12}$. To tak jakby człowiek otrzymał niezwykle cenną księgę zawierającą rady i odpowiedzi na wszelkie fundamentalne pytania, jednak nie byłby w stanie zrozumieć jej znaczenia. Dataizm wskazuje na fakt, iż większość ludzi nie radzi sobie $z$ racjonalnym sposobem przetwarzania danych, który został ujęty w gradacyjnym schemacie poznawczym formułą: zbiór informacji prowadzi do uzyskania wiedzy o X, zaś określona ilość wiedzy o X pozwala na manifestację mądrości (np. w formie decyzji lub określonego działania) przez daną osobę. W zamian za możliwość przetwarzania „wszystkich” informacji dataiści pragmatycznie zgadzają się na to, by obecnie nie przekształcać ich $\mathrm{w}$ inną wiedzę niż operacyjna. Nawet jeśli założymy, że algorytmy komputerowe SI są w stanie, w sposób (nie)świadomy, wyznaczać ludziom cel (sens działania), a dopiero później przesyłać je dalej, to pojawia się kolejny rodzaj niebezpieczeństwa, związany z radykalizacją sporu politycznego czy kulturowego. Gdy jeden $z$ algorytmów stanie się dominującym „podmiotem decyzyjnym”, z najlepszą wiedzą w zakresie praktycznego wykorzystania informacji, alternatywne scenariusze rozwoju cywilizacyjnego zostaną ograniczone do minimum (na skalę uzależnienia malejący wpływ mają jeszcze państwa), nie mamy jednak pewności jakiego rodzaju wiedzy będzie on dostarczał, jakie rozwiązania ustrojowe proponował itd. Prawo Godwina powiada, iż Hitler kończy każdy wątek, zatem przypomnieć warto polityczne wykorzystanie nauki przez nazistów (Horkheimer, Adorno 1994, s. 192-193), które może zostać (w najgorszej sytuacji) zaproponowane ludziom przez SI.

12 Fizyk komputerowy Max Tegmark napisał przydatną książkę na temat etycznych kontrowersji wokół sztucznej inteligencji Życie 3.0. Człowiek w erze sztucznej inteligencji (2019). 
Zdaniem Harariego droga dataizmu jest „lepsza”, ponieważ technohumanizm w pewnym sensie dąży do „ogołocenia” człowieka $z$ jego człowieczeństwa: „Jeśli połączymy praktyczną umiejętność projektowania umysłu $\mathrm{z}$ naszą niewiedzą co do spektrum psychicznego oraz $\mathrm{z}$ wąskimi interesami rządów, armii i korporacji, mamy gotową receptę na kłopoty. Co więcej, technohumanizm może prowadzić nawet do degradacji człowieka. Być może system będzie wolał takich celowo upośledzonych ludzi nie dlatego, że będą posiadali jakieś nadludzkie talenty, ale dlatego, że będzie im brakowało pewnych naprawdę niepokojących ludzkich cech, które przeszkadzają systemowi i go spowalniają. [...] Druga rewolucja poznawcza, o której marzą technohumaniści, mogłaby zrobić to samo z nami, tworząc ludzkie trybiki, które porozumiewają się i przetwarzają dane dużo skuteczniej niż kiedykolwiek wcześniej, ale prawie nie potrafią skupić na niczym uwagi, śnić ani wątpić" (Harari 2018, s. 407). O dziwo, nie dostrzega on, że w świecie dataizmu człowiek staje się dokładnie taki, jakim opisuje go w epoce transhumanistycznej. Człowiek podległy zimnej kalkulacji algorytmów, które z zasady się „nie mylą”, mógłby wieść rajski żywot, bez uciążliwej intelektualnie konieczności decydowania.

„Skłonność ludzkich umysłów do podlegania memetycznym zarażeniom może mieć znaczenie nie tylko dla producentów ubrań, płyt czy filmów. Każde odkrycie dotyczące mechanizmów masowego szerzenia się poglądów i zachowań stanowi nowe wyzwanie dla socjotechników. Ich koncepcje są $z$ kolei wykorzystywane $\mathrm{w}$ reklamie oraz $\mathrm{w}$ politycznej i religijnej indoktrynacji. [...] Czy wkrótce będziemy głosować na polityków, którzy tak naprawdę w ogóle nam nie odpowiadają? Czy będziemy bezwolnie kupować niepotrzebne nam rzeczy, a większość wolnego czasu spędzimy przed ekranami telewizorów?” (Biedrzycki 1998, s. 182-183). Wolność wyboru jest zasadniczym problemem w świecie, który będzie kontrolowany przez różnego rodzaju urządzenia, takie jak smart-systemy sterowania domem czy autonomiczne samochody ${ }^{13}$.

„Technohumanizm staje tu przed niemożliwym do rozstrzygnięcia dylematem. Uważa, że ludzka wola to najważniejsza rzecz we wszechświecie, dlatego nakłania ludzkość do opracowywania rozwiązań technicznych, które pozwolą kontrolować i przeprojektowywać wolę. To kusząca myśl: zdobyć kontrolę nad najważniejszą rzeczą w świecie. Czy jednak gdybyśmy kiedyś osiągnęli taką władzę, technohumanizm wiedziałby, co z nią zrobić,

${ }^{13}$ Komisja PE przegłosowała. Bliżej do automatycznego ograniczania prędkości samochodów (http:// www.brd24.pl/technika-jazdy/komisja-pe-przeglosowala-blizej-do-automatycznego-ogranic zania-predkosci-samochodow/ [dostęp: 28.02.2019]). 
skoro człowiek, czczony przez niego jako święty, stałby się po prostu kolejnym produktem do zaprojektowania zgodnie z zamówieniem? Nigdy nie będziemy potrafili sobie radzić z taką technologią, dopóki będziemy uważali, że ludzka wola i ludzkie doświadczenie to najwyższe źródło władzy i sensu" (Harari 2018, s. 412). Harari podkreśla jednak, że człowiek pozostawiony samemu sobie nie musi dokonywać właściwych wyborów, na przykład może się pomylić, ulec religijnej indoktrynacji itp. Obecnie oferowany jest mu „za darmo" świat, w którym mądrzejsze od niego algorytmy będą lepiej wiedziały, co jest mu potrzebne. „Humanistyczne zalecenie, by słuchać samego siebie, zrujnowało życie niejednemu człowiekowi, podczas gdy odpowiednie dawkowanie właściwych substancji chemicznych znacznie przyczyniło się do poprawy samopoczucia milionów ludzi" (Harari 2018, s. 409).

Wizja ta, rodem z Nowego wspaniałego świata Aldousa Huxleya, nie bez powodu uznawana jest za rodzaj antyutopii (czy nawet dystopii). Jak pisał Jerzy Szacki (2000, s. 190-192), (anty)utopia opisana przez Huxleya, nawet pozornie realizująca wizję „doskonałego” świata, pozbawionego wielu znanych nam obecnie problemów, jawi się jako forma totalitaryzmu, z racji jego „jednomyślnego” i zamkniętego charakteru, którego nie można podważyć ani zakłócić. Ludzie zaś, kierujący się wieloma różnymi ideami, wartościami itp., musieliby zgodzić się $\mathrm{w}$ ramach dataizmu na poddanie się „racjonalności systemu przetwarzania danych”, choć nie ma jakichkolwiek przesłanek dotyczących tego, jaki świat stworzyłyby człowiekowi algorytmy. Technologia czeka na polityczne i aksjologiczne cele.

\section{SŁOWO KOŃCOWE}

Jak już wspomnieliśmy, Manuel Castells (2000, s. 230-232) używał terminu ,informacjonalizacja” na określenie generalnego wpływu technologii informacyjnych i komunikacyjnych na strukturę ekonomiczną, polityczną i społeczną, przy czym cechą wyróżniającą nowy typ społeczeństwa byłaby globalna cyfrowa sieciowość. Pojęcie informacjonalizacji jest znaczeniowo szersze od pojęcia informatyzacji, którą zwykle utożsamia się $z$ algorytmami big data, smartfonami czy sztuczną inteligencją. Pojęcie informacjonalizacji obejmuje zjawiska z sfery społecznej, jak demokratyzacja partycypacji kulturalnej, edukacja prowadząca do wzrostu kompetencji w zakresie przetwarzania informacji czy istnienie mediów społecznościowych. Upraszczając, główny nurt informacjonalizacji historycznie prowadził do poszerzania zakresu wolności indywidualnej czy też wzrostu potencjału działania zbiorowego — od skali interpersonalnej do globalnej. 
Obok konkretnych rozwiązań technicznych na proces informacjonalizacji składają się zatem zmiany funkcji mediów i urządzeń, za pomocą których przetwarza się informacje i kontroluje uwagę podmiotów działających w skali globalnej. Funkcjonalność techniczna obejmuje dwie zasadnicze racjonalizacje: ekonomiczną oraz polityczną. Nie wchodząc w złożone relacje obu tych sfer można powiedzieć, że technologia występuje niejako $\mathrm{w}$ imię pewnych wartości, które mogą wchodzić w absurdalny konflikt $\mathrm{z}$ innymi wartościami podstawowymi ${ }^{14}$. Przyjazne użytkowanie (user interface, user friendly, user experience) jest podstawą sukcesu przyciągania uwagi, co pozwala na komunikowanie bardziej wyrafinowanych treści (zarówno w sensie jakościowym, jak i ilościowym). Zasadniczy etap postępu cywilizacji osadza się na arché, aby pamiętać, że to, co jest przyjazne dla użytkownika, było łatwe w obsłudze i dostępne dla wszystkich urządzeń, z których można wyssać dane osobowe.

Proponowana koncepcja informacjonalizacji od klasycznych teorii modernizacji w socjologii różni się otwarciem na kierunki zmiany procesu cywilizacji, gdyż ludzie reagują różnie na bodźce środowiska, ale nie wiadomo dokładnie, jaka „różnica czyni różnicę” godną medialnego odnotowania (i vice versa). W odróżnieniu od wciągającej metaforyki Harariego koncepcja informacjonalizacji wskazuje na ograniczoną „zależnością od ścieżki" kwestię architektury semantycznej i logiki działania artificial intelligence. Informacjonalizacja nie prowadzi bezwarunkowo do określenia optymalnego typu organizacji systemu społecznego (sieciowy, centralistyczny, hierarchiczny, socjalistyczny, losowy, demokratyczny, merytokratyczny, kapitalistyczny itd.). Informatyzacja (cyfryzacja, dygitalizacja) jest przeto jednym $z$ etapów bądź czynników (wariantów, elementów) procesu informacjonalizacji, kojarzonego dziś głównie z robotyzacją, mobilnym internetem czy quasi-religijnym dataizmem. Paradoksalnie, globalny system informacyjny uczy się rekursywnie na bazach własnych błędów, co czyni proces cywilizacji otwartym na funkcjonalne absurdy mediów społecznościowych, a zarazem podatnym na „genialne osobliwości”, poszerzające kulturowe ramy wiedzy instytucjonalnej dostępnej rozumowi, konkretnemu człowiekowi zaś mądrości życiowej. „To, co nazywamy mądrością, $\mathrm{w}$ znacznym stopniu polega na równoważeniu naszych wewnętrznych sprzecznych pragnień, a to, co nazywamy moralnością i polityką, polega na równoważeniu sprzecznych pragnień poszczególnych ludzi” (Pinker 2018,

14 Wybór między smartfonem a toaletą nie jest oczywisty, jesli weźmie się pod uwagę te rejony świata, które proces informacjonalizacji przeskakują etapami (Tofflerowskie „fale”), poruszając się w Nietzscheańskiej skali przewartościowania wartości. 
s. 481). Wiedza naukowa $z$ zasady podlega reklamacji, a ideały etyczne naukowców są niepodważalne.

Abraham Maslow twierdził, iż $\mathrm{w}$ niedostatku materialnym potrzeby biologiczne są pierwotne wobec potrzeb społecznych (niematerialnych niejako), ale w stanie obfitości reguły gry się zmieniają deprawacyjnie: idealnie hodowany obywatel i klient, producent i konsument ma coraz więcej powodów życiowych, aby móc realnie kontestować niesprawiedliwości systemu-świata. Cokolwiek zakłóca ci sen, jest złe. Odwołanie się do subiektywnej jaźni (,ja”, strumienia świadomości, tożsamości, pamięci faktologicznej) wpływa na możliwości instytucjonalnej kontroli działania społecznego (human action), czy to w postaci staromodnej biesiady, propagandy, farmakologii, ideologii, czy też dadaistycznych neurotechnik, opartych na faktycznych danych o zachowaniu i poglądach ,indywiduum” (Harari 2018, s. 342). Tradycja abrewiacji terminologicznej, czyniąca $z$ wiedzy skuteczny i afektywny instrument sprawowania kontroli nad masami, nie kłóci się wprawdzie z zasadami demokracji, ale komplikuje prostą ideę „ludowej mądrości”. Harari zaznacza, że zbiorowa mądrość powinna wybierać „wyróżniające się informacje”, których atutem jest wystudiowana zdolność realizacji własnych interesów dzięki umiejętności odczytywania ekstrapolacji trendów demograficznych czy znajomości rachunku prawdopodobieństwa. Atoli cyfrowa sowa Minerwy nie zawsze wylatuje o świcie komunikacyjnym ${ }^{15}$.

Schematycznie, acz klarownie ujęta idea relacji nauki i techniki stanowi jeden z najważniejszych filarów cywilizacji Zachodu i liberalnych fundamentów narracji Harariego. Od czasów industrializacji dominuje paradygmat naturalistyczny, który jest osadzony na realizmie części filozofów oświeceniowych. Już w dziełach Nicolasa de Condorceta (1957, s. XVI-XVIII) znajdziemy postulat statystycznej analizy „morfologii społecznej”, specyficznej metody, która miała stać się narzędziem poznania relacji społecznych (komunikacji), a także sposobem umożliwiającym ich kontrolę i systemowe sterowanie. Gromadzenie danych praktykowane jest od dawna, o czym świadczą źródła archeologiczne i spory historyków o metodologiczny status badań idiograficznych po ataku postmodernistów. Utylitaryzm moralny i pragmatyzm techniczny tworzą jądro oświeceniowej idei postępu, absurdalnie godzącej ambiwalentne wartości samodoskonalenia się jednostki (indywiduum) z postępem całej Ludzkości (używając stylistycznej maniery pierwszych marksistów). Przed Hararim twierdzono dobitnie, że internet to jakościowy skok w rozumieniu mechanizmów

15 Ze względu na częste przywoływanie „efektu ćmy” w odniesieniu do wpływu „sztucznej cywilizacji na orientacje życiowe” zdecydowaliśmy się na staromodne odwołanie do Hegla. 
uspołecznienia technologicznego $\mathrm{w}$ ramach kultury indywidualizmu ${ }^{16}$. Analogicznie do stadialności organicznej kondycji ludzkiej, której dalekim echem są pseudospory medialne o zabijanie dzieci nienarodzonych (status dziecka i możliwości techniczne techno-genetyki prenatalnej), analizuje się proces doskonalenia się gatunku ludzkiego w następujących po sobie epokach informacjonalizacji. Na stadialności komunikacyjnej oparł swój pozytywizm August Comte (Szacki 2006, s. 101), tworząc przy okazji (jednokierunkową) teorię dynamiki społecznej. Przeskakując niejako erę industrializacji (która nie wygasła całkowicie) do narracji z początków XXI wieku, widzimy, jak możliwości rozumu korespondują obecnie ze skłonnością do wykorzystywania praktycznych narzędzi cyfrowych, które inteligentnie pomagają jednostkom organizować życie. Pod koniec XX wieku o procesie cywilizacji pisano pod hasłem globalizacji, której ikoną mógł się stać samolot, telewizja, internet czy smartfon. Prawdopodobieństwo pojawienia się zarzewia globalnej pandemii wydaje się niższe na mało zaludnionych terenach pustynnych niźli w gigantycznych miastach populacyjnego imperium głównego nurtu medialnego.

Zebrane przez Harariego w dataistyczną całość opowieści o historii ludzkości i skutki wielowiekowego procesu informacjonalizacji są obecne w kulturze popularnej przynajmniej od początku drugiego millenium. W wersji sarkastyczno-liberalnej sens dataizmu penetrowali rockmeni: „W czarnej trumience. Na osiemnastu złoconych nóżkach śpi. Układ scalony błogosławiony. Swym algorytmem czip. Chwalmy układ za upór i trud. Chwalmy układ. Chwalmy układ scalony. Chwalmy go. Chwalmy układ za upór i trud. Chwalmy układ. I alleluja śpiewajmy mu" ${ }^{17}$. W wersji konfrontacyjnej (również z poprawną pisownią), ulica mówi: „System wypuści w ulice szperaczy. Znajdzie element i chipem oznaczy" ${ }^{18}$. Ze względu na szerokie pole interpretacyjne opisywane przez Harariego zjawiska, które nazywa on dataizmem, można zagregować do pojęcia ironicznej technozo-

16 „Kulturę indywidualizmu rozumiem tu — za Małgorzatą Jacyno — jako specyficzną dla społeczeństw późnej nowoczesności wiązkę instytucji, technik i wzorów, które zapośredniczają uspołecznienie. Opiera się ona na spsychologizowanej wizji człowieka obdarzonego niepowtarzalnym wnętrzem, które „[...] może [on] wybierać, kształtować, modelować, formować, zmieniać, edukować, może je ćwiczyć i ostatecznie może nim zarządzać. Idzie za tym przykazanie autentycznego życia w zgodzie ze sobą i poszukiwania forów ekspresji Ja poprzez kreatywność, konsumpcję i komunikację z innymi. Oś czasu - nowy sposób na wyrażenie tego, kim jesteś - oferowana jest jako poręczne narzędzie do realizacji tego postulatu" (Halawa 2013, s. 120).

17 Lech Janerka, „Allelujaż”, „Fiu, Fiu” (BMG Poland 2002).

18 Vienio, „Manifest Normalsów”, płyta „Historie Opowiadania Retrospekcje Emocje”; Hore Rekords! (2016). 
fii (zawoalowanej krytyki postępu), która nie jest wolna od prawno-etycznych dylematów politycznych, kwestii reprezentacji i prawomocności władzy. Komiksy, które wydaje obecnie Harari, są dobitnym przykładem konsekwencji działania procesu informacjonalizacji w kierunku przeciwnym do mitycznej Kukanii.

W początkach XXI wieku świat cyfrowy nadal zachowuje znamiona wolności, wybory są dobrowolnie przyjmowane i otwarte na medialną krytykę. Klika cyrkowych korporacji dzieli cyfrowy świat „za darmo” na aktywność nie będącą ani pracą, ani rozrywką. Na rynku świadczeń socjalnych „za darmo” jest mityczną Kukanią, za czym stoi wiedza praktyczna i teoretyczna, umiejętność perswazyjnego jej wykorzystania do przyciągania uwagi określonego audytorium. „Dzisiaj mieszkamy w Kukanii i naszym problemem nie jest zbyt mała, lecz zbyt duża dawka kalorii. Jak zauważył komik Chris Rock: To jest pierwsze społeczeństwo w historii, gdzie biedni są grubi. $Z$ typową dla pierwszego świata niewdzięcznością współcześni krytycy społeczni pomstują na epidemię otyłości z nasileniem oburzenia, które może byłoby stosowne w kontekście głodu (to znaczy pomstują w przerwach między pomstowaniem na stygmatyzowanie grubych, chude modelki albo zaburzenia odżywiania). Chociaż otyłość z pewnością jest społecznym problemem zdrowotnym, według kryteriów historycznych należy ją zaliczyć do całkiem przyjemnych problemów" (Pinker 2018, s. 94) ${ }^{19}$. Kiedy inteligentna automatyzacja (robotyzacja) zredukuje kolejne miejsca pracy, rządy będą musiały radykalnie zmienić politykę zatrudnienia i świadczeń socjalnych (bezwarunkowy dochód podstawowy).

Zagnieżdżone $\mathrm{w}$ długim trwaniu, ciągłe (niebinarne) i wielopoziomowe zmiany instytucji komunikacji społecznej proponujemy nazwać procesem informacjonalizacji, na który składa się trwały element strukturalny, określający warunki funkcjonowania mediów, oraz komponent osobliwości, związany z wynajdywaniem niekonwencjonalnych rozwiązań znanych i nieznanych problemów (np. metafora osobliwości i czarnych łabędzi). Innymi słowy, informacjonalizacja polega na uzależnianiu się gatunku homo od technologii komunikacyjnych i informacyjnych w każdym aspekcie funkcjonowania społeczeństwa, plemienia, klanu, rodziny, indywiduum —

\footnotetext{
19 Realizuje się dziś badania mające wykazać, czy niespodziana „eksplozja ruminacji może także wpływać na zachowania żywieniowe osób stosujących dietę wegetariańską", a ta zaś „może w niektórych przypadkach być zachowaniem restrykcyjnym i służyć regulacji emocji”. Cytujemy fragment opisu projektu badawczego Anny Brytek-Matery, w którym ruminacje to „obsesyjnie pojawiające się negatywne myśli, które nasilają nieprawidłowe nawyki związane z jedzeniem" (https://swps.pl/nauka-i-badania/granty/16442-ocena-ruminacji-i-zachowanzywieniowych [dostęp: 25.12.2017]).
} 
w czasie, w którym żyją realne podmioty, mniej lub bardziej świadomie wpływające na kierunek procesu cywilizacji ${ }^{20}$.

Dalszy ciąg historii dataizmu w wersji sceptycznej, zakładającej konfrontację technologiczno-ekonomiczną i wojnę o kontrolę nad łańcuchami dostaw (wody, surowców, energii, żywności, medykamentów), można by za Hararim streścić następująco: „Kiedy kraj zostaje pokonany w wyniku wojny, kraj naprawdę nie cierpi. To tylko metafora. Natomiast kiedy żołnierz zostaje ranny w bitwie, on naprawdę cierpi. Oczywiście cierpienie może równie dobrze powodować nasza wiara w fikcje. Na przykład wiara w mity państwowe i religijne może wywołać wybuch wojny, w której miliony stracą domy, kończyny, a nawet życie. Przyczyna wojny jest fikcyjna, ale cierpienie jest w stu procentach rzeczywiste. Właśnie dlatego powinniśmy starać się odróżniać fikcję od rzeczywistości. Fikcja nie jest zła. Jest niezbędna. Bez powszechnie przyjmowanych opowieści o takich rzeczach, jak pieniądze, państwa czy korporacje, nie może funkcjonować żadne złożone ludzkie społeczeństwo. Nie da się korzystać z dobrodziejstw wolnego rynku ani systemu sądownictwa bez podobnych opowieści tworzonych w wyobraźni. Jednak te historie to tylko narzędzia. Nie powinny stawać się naszymi celami ani miarami. Kiedy zapominamy, że to tylko fikcja, tracimy kontakt z rzeczywistością. [...] W XXI wieku będziemy tworzyli potężniejsze fikcje i bardziej totalitarne religie niż $\mathrm{w}$ jakiejkolwiek wcześniejszej epoce. $Z$ pomocą biotechnologii oraz algorytmów komputerowych te religie będą nie tylko na bieżąco kontrolowały nasze istnienie, ale będą w stanie kształtować nasze ciała, mózgi i umysły oraz tworzyć całe wirtualne światy wraz z różnymi odmianami piekła i nieba. Odróżnienie fikcji od rzeczywistości będzie zatem coraz trudniejsze, ale i bardziej niezbędne niż kiedykolwiek" (Harari 2018b, s. 225, 226).

\section{BIBLIOGRAFIA}

Biedrzycki Mariusz, 1998, Genetyka kultury, Prószyński i S-ka, Warszawa.

Bobryk Jerzy, 2014, Transhumanizm, „cognitive science” $i$ wyzwania dla nauk społecznych, „Studia Socjologiczne", nr 3, s. 9-27.

Castells Manuel, 2000, The Rise of Network Society (second edition), t. 1, International Limited, Padstow.

20 „W istocie mity są silniejsze, niż można przypuszczać. Gdy rewolucja agrarna stworzyła przesłanki do powstania zatłoczonych miast i silnych imperiów, ludzie zaczęli wymyślać opowieści o potężnych bogach, ojczyznach i spółkach akcyjnych, które dostarczały tak pożądanego spoiwa społecznego. Gdy ewolucja człowieka posuwała się właściwym sobie ślimaczym tempem, ludzka wyobraźnia budowała zdumiewające sieci masowej współpracy niepodobne do niczego, co znał świat" (Harari 2018a, s. 131-132). 
Condorcet Jean Antoine Nicolas, 1997, Szkic obrazu postępu ducha ludzkiego poprzez dzieje, tłum. Ewa Hartleb, Państwowe Wydawnictwo Naukowe, Warszawa.

Dennett Daniel, 2017, Od bakterii do Bacha. Oewolucji umysłów, tłum. Krystyna Bielecka, Marcin Miłkowski, Copernicus Center Press, Kraków.

Dijck José van, 2014, Datafication, Dataism and Dataveillance: Big Data between Scientific Paradigm and Ideology, „SS Surveillance \& Society”, t. 12, nr 2, s. 197-208.

Dyson George B., 1997, Darwin wśród maszyn. Rzecz o ewolucji inteligencji, tłum. Robert Piotrowski, Prószyński i S-ka, Warszawa.

Gałuszka Damian, Ptaszek Grzegorz, Żuchowska-Skiba Dorota, 2016, Technokultura: transhumanizm i sztuka cyfrowa, Libron, Kraków.

Goban-Klas Tomasz, 2002, Media i komunikowanie masowe, Wydawnictwo Naukowe PWN, Warszawa-Kraków.

Halawa Mateusz, 2013, Facebook - platforma algorytmicznej towarzyskości i technologia siebie, „Kultura i Społeczeństwo”, nr 4, s. 117-144.

Harari Yuval Noah, 2018, Homo deus: krótka historia jutra, tłum. Michał Romanek, Wydawnictwo Literackie, Kraków [Homo Deus: A Brief History of Tomorrow, Harper Perennial, New York 2016].

Harari Yuval Noah, 2018a, Od zwierząt do bogów, tłum. Justyn Hunia, Dom Wydawniczy PWN, Warszawa.

Horkheimer Max, Adorno Theodor W., 1994, Dialektyka oświecenia, tłum. Małgorzata Łukasiewicz, IFiS PAN, Warszawa.

Kant Immanuel, 2005, Odpowiedź na pytanie: Czym jest oświecenie?, w: Tomasz Kupś, Mirosław Żelazny (red.), Rozprawy z filozofii historii, Antyk, Kęty.

Kryszczuk Maciej, 2018, Neoluddyzm jako kategoria analityczna — próba konceptualizacji, „Transformacje”, t. 1/2 (96/97), s. 299-339.

Kryszczuk Maciej, Szymański Kamil, 2019, Komputery w środowisku pracy: historyczny zarys procesu informacjonalizacji, „Miscellanea Anthropologica et Sociologica”, t. 20(3), s. 120-140.

Kurzweil Raymond, 2013, Nadchodzi osobliwość: kiedy człowiek przekroczy granice biologii, tłum. Anna Nowosielska, Eliza Chodkowska, Kurhaus Publishing, Warszawa.

Lakoff George, Johnson Mark, 2020, Metafory w naszym życiu, tłum. Tomasz P. Krzeszowski, Aletheia, Warszawa.

Lilla Mark, 2018, Koniec liberalizmu, jaki znamy. Requiem dla polityki tożsamości, tłum. Łukasz Pawłowski, Biblioteka Kultury Liberalnej, Warszawa.

Mayer-Schönberger Victor, Cukier Kenneth, 2014, Big Data: A Revolution that Will Transform How We Live, Work and Think, Mariner Books, Boston.

More Max, 2013, A Letter to Mother Nature, w: Max More, Natasha Vita-More (red.), The Transhumanist Reader: Classical and Contemporary Essays on the Science, Technology, and Philosophy of the Human Future, Wiley-Blackwell, Chichester, West Sussex.

More Max, Vita-More Natasha, 2013, The Transhumanist Reader: Classical and Contemporary Essays on the Science, Technology, and Philosophy of the Human Future, Wiley-Blackwell, Chichester, West Sussex.

Pinker Steven, 2018, Nowe Oświecenie. Argumenty za rozumem, nauka, humanizmem i postępem, tłum. Tomasz Bieroń, Zysk i S-ka, Poznań.

Postman Neil, 1995, Technopol. Triumf techniki nad kultura, tłum. Anna Tanalska-Dulęba, Muza, Warszawa. 
Reale Giovanni, 2008, Historia filozofii starożytnej, t. 1, tłum. Edward Iwo Zieliński, Wydawnictwo KUL, Lublin.

Spitzer Manfred, 2013, Cyfrowa demencja. W jaki sposób pozbawiamy rozumu siebie i swoje dzieci, tłum. Andrzej Lipiński, Dobra Literatura, Słupsk.

Szacki Jerzy, 2000, Spotkania z utopia, Sic!, Warszawa.

Szacki Jerzy, 2006, Historia myśli socjologicznej, Wydawnictwo Naukowe PWN, Warszawa.

Szymański Kamil, 2017, Przyszłość pracy ludzkiej w czasach automatyzacji, „Transformacje”, t. 1-2 (92-93), s. 88-103.

Tegmark Max, 2019, Życie 3.0. Człowiek w erze sztucznej inteligencji, tłum. Tomasz Krzysztoń, Prószyński i S-ka, Warszawa.

\title{
Inne źródła
}

AN, Komisja PE przegłosowała. Bliżej do automatycznego ograniczania prędkości samochodów, Portal o bezpieczeństwie (http://www.brd24.pl/technika-jazdy/komisja-pe-przeglosowalablizej-do-automatycznego-ograniczania-predkosci-samochodow [dostęp: 28.02.2019]).

Blog Rafała Kinowskiego (http://antykruchosc.blox.pl/2018/01/Dataizm.html [dostęp: 18. 06.2018]).

Brooks David, The Philosophy of Data, „The New York Times” (https://www.nytimes.com/ 2013/02/05/opinion/brooks-the-philosophy-of-data.html [dostęp: 22.12.2018]).

Facebook zagrozit, że może być zmuszony zablokować Europejczykom dostęp do swych ustug, „Dziennik Gazeta Prawna” (https://serwisy.gazetaprawna.pl/media/artykuly/1492066,facebookdostep-do-uslug-uodo-wyrok-tsue.html [dostęp: 20.12.2020]).

Janerka Lech, „Allelujaż”, „Fiu, Fiu” (BMG Poland 2002).

Vienio, „Manifest Normalsów”, płyta „Historie Opowiadania Retrospekcje Emocje”; Hore Rekords! (2016).

\section{INFORMATION AS ARCHE, OR AN OUTLINE OF YUVAL NOAH HARARI'S CONCEPT OF DATAISM}

\author{
Maciej Kryszczuk (Institute of Labour and Social Studies), \\ Kamil Szymański (Maria Curie-Skłodowska University, \\ Catolic University of Lublin)
}

\begin{abstract}
The authors discuss Yuval Noah Harari's concept of dataism, which is part of a wider stream of debate on the future of civilization. Depending on the analytical perspective and the type of narration, dataism has been characterized as a kind of faith, an ideology, a worldview, or a set of (conscious) attitudes for which information is a kind of arche. The popularizer of the concept, the anthropologist Yuval Harari, argues that acts of dataism are a useful praxis of the twenty-first century, consisting in the deliberate-but also partly involuntary-entrusting of one's life affairs (and not only) to algorithms that process data from popular digital devices
\end{abstract}


such as a smartphone. Among the many significant effects of digitization, the authors point to changes in the spheres of work and capital which have the potential to produce a profound political and moral revolution.

key words: Yuval Noah Harari, dataism, homo deus, informationalization, social change

stowa kluczowe: Yuval Noah Harari, dataizm, homo deus, informacjonalizacja, zmiana społeczna 